\title{
Unormalt feste av navlesnoren øker risiko for blødning
}

\author{
Velamentøst eller marginalt feste av navlesnoren er forbundet med økt \\ risiko for komplikasjoner i fødselens etterbyrdsfase.
}

Navlesnoren er vanligvis festet på morkaken, men kan i noen tilfeller ha et unormalt feste i fosterhinnen (velamentøst feste) eller i kanten av morkaken (marginalt feste). Et unormalt navlesnorfeste er forbundet

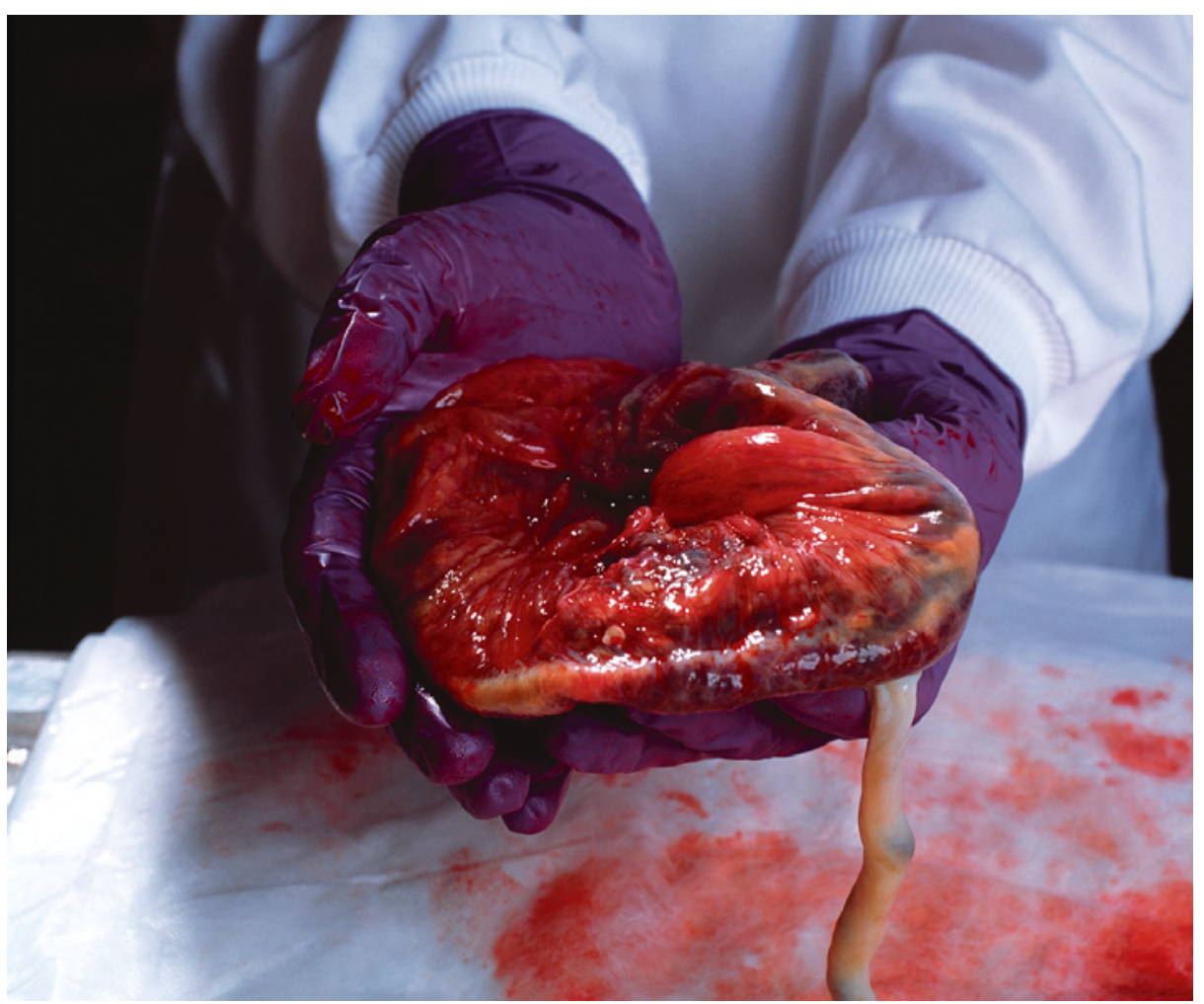

\section{Mindre demens blant overvektige?}

\section{Undervektige blir oftere demente, og overvekt synes å gi relativ beskyttelse mot å utvikle demens, ifølge en nylig publisert studie.}

Demens og fedme er vanlige tilstander som øker i forekomst, og det er antydet at overvekt predisponerer for demens, slik det gjør for mye annen sykdom.

I en nylig publisert observasjonsstudie $\mathrm{i}$ Lancet Diabetes \& Endocrinology med nesten to millioner briter i alderen 44-66 år falt risikoen for å utvikle demens innen ni år med økende kroppsmasseindeks (BMI) (1). Svært overvektige personer (BMI $>40 \mathrm{~kg} /$ $\mathrm{m}^{2}$ ) hadde $29 \%$ lavere risiko for å utvikle demens sammenliknet med normalvektige med økt risiko for komplikasjoner i svangerskapet og økt perinatal mortalitet. En nylig publisert studie har undersøkt om unormalt navlesnorfeste øker risikoen for komplikasjoner i etterbyrdsfasen av fødselen (1).

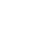

\section{(a)} $2,87-3,77$ ) og postpartumblødning (oddsratio 2,$06 ; 1,77-2,39$ ).

- Dette er en vel gjennomført populasjonsbasert studie fra Norge der styrken ligger i studiens størrelse. Dette gjør det mulig å studere tilstander som forekommer sjelden, sier Kari Flo, overlege ved Kvinneklinikken, Akershus universitetssykehus og førsteamanuensis ved Universitetet i Tromsø.

- Velamentøst og marginalt feste av navlesnor kan diagnostiseres med ultralydundersøkelse i svangerskapet, men dette er ikke en del av den rutinemessige undersøkelsen som tilbys gravide i dag. Hvordan et slikt funn bør følges opp videre under svangerskap og fødsel er ikke klart. Det kan være aktuelt å studere nytteverdien av å identifisere velamentøst og marginalt feste av navlesnor ved ultralydundersøkelse, sier Flo.

\section{Lise Mørkved Helsingen \\ Tidsskriftet \\ Litteratur \\ 1. Ebbing C. Kiserud T, Johnsen SL et al. Third stage of labor risks in velamentous and marginal cord insertion: a population-based study. Acta Obstet Gynecol Scand 2015; e-publisert 4.5.2015.}

(BMI rundt $25 \mathrm{~kg} / \mathrm{m}^{2}$ ). Undervektige (BMI $<20 \mathrm{~kg} / \mathrm{m}^{2}$ ) hadde $34 \%$ høyere risiko for å utvikle demens.

- Denne studien støtter den konvensjonelle oppfatningen om et «overvektsparadoks»), nemlig at overvekt midt i livet gir økt risiko for kognitiv svikt og demens, mens overvekt i høy alder beskytter (2), sier professor i nevrologi Tormod Fladby ved Akershus universitetssykehus. - Studien inkluderer flest pasienter med demens i relativt ung alder, og det ble søkt etter demens, Alzheimers sykdom, lewylegemesykdom og Picks sykdom, men ikke cerebrovaskulær sykdom og vaskulær demens. Det er ikke tatt hensyn til hypertensjonsbehandling, tromboseprofylakse og andre forhold som kan påvirke sammenhengen mellom ernæringsstatus og demens, påpeker Fladby.
Interaksjonen mellom Alzheimers sykdom og cerebrovaskulær sykdom er sannsynligvis viktigere i høyere aldersgrupper. Før et eventuelt overvektsparadoks kan avskrives, må man skaffe data som beskriver demenssykdommer separat, inkludert vaskulær demens, i aldersgruppene der demens er vanligst, sier Fladby.

\section{Inge Rasmus Groote}

Tidsskriftet

\section{Litteratur}

1. Qizilbash N, Gregson J, Johnson ME et al. BMI and risk of dementia in two million people over two decades: a retrospective cohort study. Lancet Diabetes Endocrinol 2015; 3: 431-6.

2. García-Ptacek S, Faxén-Irving G, Cermáková P et al. Body mass index in dementia. Eur J Clin Nutr 2014; 68: 1204-9. 